\title{
Antimicrobial Susceptibility of Campylobacter jejuni and C. coli Strains Isolated from Poultry and Pigs in the Czech Republic
}

\author{
M. MIKULIČOVÁ ${ }^{1}$, I. STEINHAUSEROVÁ ${ }^{1}$, G. BOŘILOVÁ ${ }^{1}$, M. NEBOLA ${ }^{1}$ \\ ${ }^{1}$ Department of Meat Hygiene and Technology, Faculty of Veterinary Hygiene and Ecology, \\ University of Veterinary and Pharmaceutical Sciences Brno, Czech Republic \\ Received April 26, 2005 \\ Accepted November 10, 2005
}

\begin{abstract}
Mikuličová M., I. Steinhauserová, G. Bořilová, M. Nebola: Antimicrobial Susceptibility of Campylobacter jejuni and C. coli Strains Isolated from Poultry and Pigs in the Czech Republic. Acta Vet. Brno 2005, 74:639-644.

Antimicrobial resistance has emerged among Campylobacter spp. mainly due to use of antimicrobial agents in animal feed. A total of 219 samples containing Campylobacter spp. were detected in our research during the course of 2003/4. The samples, originating from chicken (101) and pigs (118) were tested for their resistance to selected antibiotics. Evaluation of results was carried out using agar dilution method (NCCLS M11-A6) to test the sample resistance against ampicillin, tetracycline, chloramphenicol, erythromycin, gentamicin, ciprofloxacin and nalidixic acid. The $C$. jejuni strain from pigs mainly showed a high resistance to tetracycline $(39.13 \%)$ and erythromycin (34.78\%). Approximately a quarter $(26.07 \%)$ of $C$. jejuni detected was resistant to ampicillin and ciprofloxacin $(26.09 \%)$. C. coli isolates from pigs showed simular results to $C$. jejuni, such as resistance to tetracycline $(60.71 \%)$ and erythromycin $(56.84 \%)$. On the other hand, it was found that $C$. jejuni in pigs had a high resistance to ciprofloxacin $(52.63 \%)$ and nalidixic acid $(34.74 \%)$. C. jejuni isolates from chicken samples had the highest resistance to ciprofloxacin (45.21\%) and ampicillin (27.40\%), and a low resistance to erythromycin (13.70\%). A quarter of the samples collected were resistant to nalidixic acid. In comparison of $C$. jejuni prevalence, resistance to tetracycline $(21.92 \%)$ was lower in chicken than in pig samples. Similar to results of porcine meat analysis, $C$. jejuni isolated in chickens showed no resistance to chloramphenicol and a low resistance to gentamicin. $C$. coli strains found in chickens showed high resistance to nalidixic acid $(60.71 \%)$ and ciprofloxacin (46.43\%). Even though laws prevent the use of antimicrobial material in feed for livestock, their resistance to fluoroquinolone antibiotics is high. Prevention of the use of antimicrobial material in feed is the most precise control in raising livestock.
\end{abstract}

Campylobacteriosis, resistance, antibiotic, treatment

Campylobacter spp. was originally found to occur in nutrition-related illnesses. Today illnesses caused by Campylobacter spp. and salmonella presence in food are still very common in developed European countries. Majority of cases of infection in humans are caused by the Campylobacter spp. strain $C$. jejuni and in some cases $C$. coli (Steinahuserová and Nebola 2002).

Campylobacter spp. can be present in the intestinal tract of warm blooded animals without evoking clinical symptoms of disease in them. Young or immunodeficient animals can develop a gastrointestinal type illness if infected with $C$. jejuni. Commonly, carriers of $C$. jejuni are previously exposed to free range birds or chickens. Occurrence of Campylobacter spp. in chicken and turkey is estimated at $60-80 \%$, but according to some authors, occurrence in some populations has been found to be as high as $100 \%$. Campylobacter spp. in pigs is also relatively frequent, although $C$. coli is the most commonly isolated strain. Occurrence in other farm animals such as sheep and cattle is also not uncommon. Prevalence of Campylobacter spp. depends on hygienic conditions and the manner in which the animals are bred (Moore at al. 2002).

Animal preparation packages containing antibiotics were distributed throughout farm 
regions in Europe (Teuber 2001) in an attempt to improve the economic growth and increase the intensity of breeding farm animals. These preparation packages were distributed for growth enhancement or sub-therapeutic doses for the prevention of certain illnesses. From a long term perspective, the use of these antibiotics led to selection and resistance to some antibiotics, which in turn became less effective in human treatments. This resulted in an increase in human illnesses and in turn increased the usage of antibiotics in the treatment of more severe infections. This is why resistance to antibiotics has become an increasing focus and steps have been taken to prevent further accumulation of resistant strains. States of the European Union have stopped using and in some cases banned use of antibiotics in feed mixtures for livestock (Teuber 2001). Nevertheless in the interest of the European states, the resistance of strains is continually being monitored. The Czech Republic has not introduced a systematic approach to the monitoring of resistance and until recently did not have a method for the evaluation of Campylobacter spp. resistance. An evaluation method for Campylobacter spp. resistance at our laboratories has been established and in the last few years has been used to asses the resistance of Campylobacter spp. isolated from farm animals. A study of resistant strains of Campylobacter spp. isolated from humans is also being simultaneously carried out. The aim of this work was to asses the resistance of isolated strains of $C$. jejuni and C. coli isolated from pigs and chickens to selected antibiotics.

\section{Materials and Methods}

A total of 101 samples of Campylobacter spp. isolated from poultry and 118 strains from pigs were assessed during 2003 and 2004. Samples were obtained as swabs from the surface of animal flesh at slaughterhouses and at retail outlets. Examinations were carried out by cultivation methods and biochemical tests according to $1998 \mathrm{CSN}$ ISO 10272 guidelines. Species identification of isolated Campylobacter spp. was confirmed by use of polymerase chain reaction (PCR) technique with specific primers and by digestion with AluI endonuclease (Fermér and Engvall 1999).

The agar dilution method was used in testing the susceptibility of Campylobacter spp. strains to the selected antimicrobial agents. Antimicrobial susceptibility testing was done according to the NCCLS document M11 - A6 standard (2004). Seven antimicrobials were tested: ampicillin (8-32 $\mu \mathrm{g} / \mathrm{ml})$ (SA9518, Sigma-Aldrich, Prague, CZ), tetracycline (1-4 $\mu \mathrm{g} / \mathrm{ml})$ (ST7660, Sigma-Aldrich, Prague, CZ), nalidixic acid (8-32 $\mu \mathrm{g} / \mathrm{ml})$ (SN4382, SigmaAldrich, Prague, CZ), chloramphenicol (8-32 $\mu \mathrm{g} / \mathrm{ml})$ (SC0378, Sigma-Aldrich, Prague, CZ), erythromycin $(1-8 \mu \mathrm{g} / \mathrm{ml})$ (SE5389, Sigma-Aldrich, Prague, CZ), ciprofloxacin $(0.125-1 \mu \mathrm{g} / \mathrm{ml})$ (Ciprinol 100mg/50ml, Krka, $\mathrm{PL})$ and gentamicin $(0.5-4 \mu \mathrm{g} / \mathrm{ml})$ (SG1914, Sigma-Aldrich, Prague, CZ).

Mueller-Hinton agar (CM0337, Dioxo-Oxoid, Prague, CZ) supplemented with 5\% sheep blood (Bioveta, Ivanovice na Hane, CZ) was used for screening the samples. The prepared medium was mixed on Petri dishes with solutions of antimicrobial agents at specified concentrations. The antibiotic ciprofloxacin was diluted to a final concentration of $128-0.25 \mathrm{mg} / \mathrm{l}$, and gentamicin to $32-0.063 \mathrm{mg} / \mathrm{l}$. The Petri dishes were then inoculated with $2 \mu \mathrm{l}$ of bacterial suspension.

The inoculum was prepared by a 48-hour culture in Brain Heart Infusion (CM225, Dioxo-Oxoid, Prague, CZ). The suspension was adjusted to $0.5 \mathrm{McF}$ arland (the final cell number $10^{4-5} / \mathrm{ml}$ ). Incubation was carried out at $42^{\circ} \mathrm{C}$ in micro-aerobic conditions (Gas Generating Kit Campylobacter system, BR 060A, Dioxo-Oxoid, Prague, $\mathrm{CZ}$ ) for 48 hours (Aarestrup et al., 1997). The collection strain of Campylobacter jejuni subsp. jejuni ATCC 33560 was used as a control (FCCM, Prague, CZ).

\section{Results}

A total of 219 samples containing Campylobacter spp. were detected in our research during the course of 2003/4. Of these samples, 101 originated in chicken and 118 from pigs. Of the 88 positive pigs tested in 2003, 19 were identified as C. jejuni and 69 were found to be C. coli. In 2004, 30 samples of pig origin tested positive to Campylobacter spp., from which 4 and 26 samples were identified as $C$. jejuni and $C$. coli resppectively.

During the experiment, 101 samples originating from chicken were tested. From samples taken in 2003, 52 tested positive for Campylobacter spp. Majority of the isolates contained C. jejuni (43) and the rest were identified as C. coli (9). In 2004, 49 samples of chicken were examined and 30 were confirmed to contain C. jejuni and 19 were identified as C. coli. 
C. jejuni originating from pigs mainly showed a high resistance to tetracycline (39.13\%) and erythromycin (34.78\%). A total of $47 \%$ of the $C$. jejuni isolated showed an intermediate resistance to erythromycin. No resistance of $C$. jejuni to chloramphenicol and gentamicin was found. An estimated quarter (26\%) of C. jejuni was resistant to ampicillin and ciprofloxacin, with about $40 \%$ of these being intermediate with respect to ciprofloxacin resistance. No significant differences in pigs were found when comparing results from 2003 to 2004 (Table 1).

Table 1. Resistence of $C$. jejuni and $C$. coli strains isolated from poultry and pigs during 2003/4

\begin{tabular}{|l|c|c|c|c|}
\hline $\begin{array}{l}\text { Antimicrobial } \\
\text { agent }\end{array}$ & $\begin{array}{c}\text { C. jejuni } \\
\text { strains } \\
\text { isolated from } \\
\text { poultry (\%) }\end{array}$ & $\begin{array}{c}\text { C. coli strains } \\
\text { isolated from } \\
\text { poultry (\%) }\end{array}$ & $\begin{array}{c}\text { C. jejuni } \\
\text { strains } \\
\text { isolated from } \\
\text { pigs (\%) }\end{array}$ & $\begin{array}{c}\text { C. coli strains } \\
\text { isolated from } \\
\text { pigs (\%) }\end{array}$ \\
\hline Ampicillin & $20(27.40)$ & $7(25.00)$ & $6(26.07)$ & $6(6.32)$ \\
\hline Tetracycline & $16(21.92)$ & $7(25.00)$ & $9(39.13)$ & $60(63.16)$ \\
\hline Nalidixic acid & $18(24.66)$ & $17(60.71)$ & $2(8.70)$ & $33(34.74)$ \\
\hline Chloramphenicol & $0(0.00)$ & $0(0.00)$ & $0(0.00)$ & $0(0.00)$ \\
\hline Erythromycin & $10(13.70)$ & $4(14.29)$ & $8(34.78)$ & $54(56.84)$ \\
\hline Ciprofloxacin & $33(45.21)$ & $13(46.43)$ & $6(26.09)$ & $50(52.63)$ \\
\hline Gentamicin & $4(5.48)$ & $7(25.00)$ & $0(0.00)$ & $6(6.32)$ \\
\hline $\mathrm{n}(\%)$ & $73(72.28)$ & $28(27.72)$ & $23(19.49)$ & $95(80.51)$ \\
\hline $\mathrm{n}$ & 101 & & 118 & \\
\hline
\end{tabular}

C. coli isolated from pig samples showed similar results to $C$. jejuni. Results showed strong resistance to tetracycline $(63.16 \%)$ and erythromycin (56.84\%). Unlike C. jejuni, a high resistance to ciprofloxacin $(52.63 \%)$ and nalidixic acid $(34.74 \%)$ was found. C. coli also showed and intermediate resistance to ciprofloxacin. Again no resistance to chloramphenicol and a very low resistance to gentamicin and ampicillin were shown by $C$. coli in pig. By comparison of the 2 years studied, C. coli resistance to ciprofloxacin was found to be higher in 2004 although resistance to nalidixic acid and erythromycin notably declined.

The situation regarding samples isolated from chicken was considerably different (Table 1). C. jejuni was most resistant to ciprofloxacin (45.21\%) and ampicillin $(27.40 \%)$. On the other hand C. jejuni isolated from pigs showed low resistance to erythromycin $(13.70 \%)$ and a quarter of the samples tested were resistant to nalidixic acid. From comparison of results resistance to tetracycline $(21.92 \%)$ was lower in chickens than in pigs. Like in pigs, C. jejuni isolated from chickens did not show any resistance to chloramphenicol and only a low resistance to gentamicin $(25.00 \%)$. Further comparison of 2003 to 2004 showed a distinct growth in C. jejuni resistance to ciprofloxacin and partly to ampicillin and a decline in tetracycline resistance.

C. coli strains originating from chicken showed high resistance to nalidixic acid $(60.71 \%)$ and ciprofloxacin (46.43\%). In comparison with C. jejuni, C. coli displayed a greater resistance to gentamicin. In 2004, a larger number of isolated strains were resistant to ampicillin, erythromycin and ciprofloxacin. A partially lower number of isolated C. coli strains were resistant to tetracycline.

\section{Discussion}

The use of antibiotics in human medicine and in veterinary practice has been commonly widespread. Approximately one half of antimicrobial agents produced annually in the world are estimated to be consumed for veterinary purposes (Teuber 2001). 
Frequent use of antibiotics, mainly in low doses, results in the resistance of pathogenic organisms. As a consequence, administration of antimicrobial agents to livestock has been significantly reduced, and in many cases totally forbidden in individual European countries including the Czech Republic.

In the past few years, a rapidly increasing proportion of Campylobacter spp. strains found worldwide have shown resistance to fluoroquinolone antibiotics, such as the ones mentioned above. The number of cases involving antimicrobial-resistant campylobacter's has increased in developing counties where antibiotic usage is relatively unrestricted. Primary resistance to quinolone therapy in humans was first noted in the early 1990's in Asia and in European countries. The resistance coincided with initiation of the administration of the fluoroquinolone antibiotic, enrofloxacin (a derivative of ciprofloxacin), to animal feed e.g. broiler chicken feed. The majority of $C$. jejuni fluoroquinolone-resistant isolates have a mutation in $g y r A$ that results in the substitution Thr-86 by Ile (Grigg s et al. 2005). Despite poultry companies halting the usage of fluoroquinolone for treating flocks, fluoroquinolone resistance persists in the poultry environment. Campylobacter jejuni has become increasingly resistant to fluoroquinolone antibiotics. When fluroquinolone-susceptible and fluoroquinolone-resistant Campylobacter spp. isolates are co-inoculated into chickens, the fluoroquinolone-resistant strains out compete the majority of the fluoroquinolonesusceptible strains, indicating that the resistant Campylobacter spp. are biologically fitter in the chickens (Price et al. 2005). We found that in the Czech Republic a high number of strains of Campylobacter spp. are mainly isolated from chicken that are resistant to fluoroquinolone (ciprofloxacin and nalidixic acid). A high abundance of fluoroquinoloneresistant strains have been found in other European countries. In Germany for instance more than $55 \%$ of strains isolated are resistant to nalidixic acid; high occurrence is also found in Italy (45\%) and in the USA (41\%) (Pezzoti et al. 2002; Ge et al. 2003).

Antibiotics of the macrolide-lincosamide group have been used to treat feed for livestock. The most commonly used agents for controlling dysentery and mycoplasma infection in pigs were lincomycin and tylosin. Tylosin was also the most commonly used agents for growth promotion in swine production, whereas spiramycin was used for the same purpose in poultry. Since 1999, the use of macrolides for growth promotion has been banned in all EU counties (Teuber 2001).

In $C$. jejuni and $C$. coli, erythromycin resistance is chromosomally mediated and is due to an alteration in the ribosome (Engberg et al. 2001). Despite decades of usage, the rate of resistance of Campylobacter to erythromycin remains relatively low (Snelling et al. 2005). In the Czech Republic the rate of erythromycin resistance in strains of Campylobacter jejuni from poultry and pigs seem to be relatively low as well. Similar results of low erythromycin-resistant strains in Sweden, France, Ireland and Japan have also been published (Kanako et al. 2004; Rönner et al. 2004; Avrain et al. 2003). On the other hand, more than half of the $C$. coli isolates from pigs were resistant to erythromycin. Also results indicating that the prevalence of resistance to erythromycin is generally higher in $C$. coli isolated from pigs than in C. jejuni in animal feed has also been published (Engberg et al. 2001). This is most likely due to the common use of erythromycin in the raising of pigs and the lingering of resistant strains after the banning of the antibiotic in feeding mixtures.

All of the isolated Campylobacter spp. strains showed significant resistance to tetracycline. Tetracycline resistance can be mediated by different mechanisms e.g. efflux, modification of tetracycline and mutations in 16S rDNA (Aarestrup, F. and Engberg J. 2001). More importantly, $C$. coli strains isolated from pig were found to be more resistant $(59 \%)$. This corresponds with the results of other authors from France, Italy or Germany where the resistance percentage of $C$. coli strains is between $61-79 \%$, and resistance of $C$. jejuni has so far been relatively low (Pezzotti et. al. 2002 Avrain et al. 2003). 
With the exception of macrolides, fluoroquinolones and tetracycline, antimicrobial resistance does not seem to be widesppread among Campylobacter spp. Therefore we can conclude that resistance to amino glycosides and chloramphenicol is still general low. Resistance to macrolides and fluoroquinolones is mediated by chromosomal mutations and not by horizontally acquired genes. This suggests that Campylobacter spp. may have acquired resistance genes from other bacterial species.

On the basis of our findings and comparison of results from other authors, it is clear that the problems relating to Campylobacter spp. and its resistance to antibiotics is still current, even after the restriction of the use of antibiotic in feed for livestock. To circumvent the development of resistance there are two options: infection control (zoonoses control) and prudent use of antibiotics.

\section{Hodnocení antimikrobiální rezistence kmenů Campylobacter jejuni a C. coli izolovaných $\mathrm{z}$ drůbeže a prasat $\mathrm{v}$ České republice}

Rezistence mikroorganismů včetně Campylobacter sp. vůči antibiotikům je značně rozšířena díky používání antimikrobních látek v chovech zvířat.

V průběhu roku 2003 a 2004 byla hodnocena citlivost k vybraným antibiotikům u 219 kmenů Campylobacter spp. izolovaných z drůbeže (101 kmenů) a z prasat (118 kmenů). Sledování antibiotické rezistence bylo prováděno pomocí agarové diluční metody (NCCLS M11-A6, 2004) a posuzována byla rezistence k ampicilinu, tetracyklinu, chloramfenikolu, erytromycinu, gentamicinu, ciprofloxacinu a kyselině nalidixové.

Kmeny $C$. jejuni pocházející $\mathrm{z}$ prasat vykazovaly vysokou rezistenci především k tetracyklinu $(39.13 \%)$ a erytromycinu $(34.78 \%)$. Zhruba čtvrtina $(26.07 \%)$ kmenů $C$. jejuni byla rezistentní k ampicilinu a ciprofloxacinu (26.09\%). Kmeny C. coli izolované z prasat vykazovaly, podobně jako $C$. jejuni, silnou rezistenci na tetracyklin $(63.16 \%)$ a erytromycin $(56,84 \%)$. Na rozdíl od $C$. jejuni byla zjištěna i vysoká rezistence $\mathrm{k}$ ciprofloxacinu $(52,63 \%)$ a kyselině nalidixové $(34.74 \%)$.

$\mathrm{U}$ kmenů izolovaných $\mathrm{z}$ drůbeže byla nejvyšší rezistence $C$. jejuni zaznamenána k ciprofloxacinu $(45.21 \%)$ a $\mathrm{k}$ ampicilinu (27.40\%). Na rozdíl od kmenů C. jejuni izolovaných z prasat byla prokázána nízká rezistence k erytromycinu (13.70\%) ale čtvrtina kmenů byla rezisentní vůči kyselině nalidixové. Kmeny $C$. coli pocházející z drůbeže vykazovaly vysokou rezistenci ke kyselině nalidixové $(60,71 \%)$ a ciprofloxacinu (46.43\%).Ve srovnání s kmeny $C$. jejuni pocházejících z prasat byla u drůbeže nižší rezistence k tetracyklinu (21.92\%). Kmeny $C$. jejuni izolované z drůbeže i z prasat byly senzitivní $\mathrm{k}$ chloramfenikolu a vůči gentamicinu vykazovaly nízkou rezistenci.

I přes zákaz podávání antimikrobních látek $\mathrm{v}$ krmivech je rezistence především u flurochinolonových antibiotik vysoká. Prevencí je důsledná kontrola podávání antimikrobních látek v chovech zvířat.

\section{Acknowledgements}

This project was supported by a grant from the Ministry of Agriculture NAZVA QF 3085 and research project Ministry of Education, Youth and Sport MSM6215712402.

\section{References}

AVRAIN L, HUMBERT F, L'HOSPPITALIER R, SANDERS P, VERNOZY- ROZARD CH, KEMPF I 2003: Antimicrobial resistance in Campylobacter from broilers: association with production type and antimicrobial use. Vet Microbiol 96: 267-276

ČSN ISO 10272. 1998: Mikrobiologie poživatin a krmiv - Horizontální metoda průkazu termotolerantních druhů rodu Campylobacter.

ENGBERG J, AARESTRUP FM, TAYLOR DE, GERNER-SMIDT P, NACHAMKIN I 2001: Quinolone and Macrolide Resistance in Campylobacter jejuni and C. coli: Resistance Mechanisms and Trends in Human Isolates. Emerg Infect Dis 1: 24-34 
FRANK M, JORGEN E 2001: Antimicrobial resistance of thermophilic Campylobacter. Vet Res 32: $311-321$

FERMÉR CH, ENGVALL EO, 1999: Specific PCR Identification and Differentiation of the Thermophilic Campylobacters, Campylobacter jejuni, C. coli, C. lari and Campylobacter upsaliensis. J Clin Microbiol 37: 33703373

GE BL, WHITE DG, MC DERMONTT PF, GIRARD W, ZHAO SH, HUBERT S, MENG JH 2003: Antimicrobial-resistant Campylobacter species from retail raw meats. Appl Environ Microbiol 69: 3005-3007

GRIGGS DJ, JOHNSON MM, FROST JA, HUMPHREY T., JORGENSEN F, PIDDOCK LJ 2005: Incidence and mechanism of ciprofloxacin resistance in Campylobacter spp. isolated from commercial poultry flocks in the United Kingdom before, during, and after fluoroquinolone treatment. Antimicrob Agents Chemother 49: 699707

KANAKO I, TOMOKO K, KAORI O, AYAKO M, AKEMI K, MAYUNI KT, TOSHIO T, YUAKA T 2004: Antimicrobial susceptibilities of Campylobacter isolated from food-producing animals on farm (1999-2001): results from Japanese Veterinary Antimicrobial Resistance Monitoring Program. Int J Antimicrob Agents 24: 63- 39

MOORE JE, GARCIA MM, MADDEN RH 2002: Subsppecies characterization of porcine Campylobacter coli and Campylobacter jejuni by multilocus enzyme electrophoresis typing. Vet Res Com 26: 1-9

NATIONAL COMITEE FOR CLINICAL LABORATORY STANDARDS. 2004: Methods for Antimicrobial Susceptibility Testing of Anaerobic Bacteria-Sixth Edition: Approved Standard M11-A6. NCCLS, Villanova, PA, USA.

PATTE M, OCEPEK M, ZOLNIR-DOVC KRT B 2005: Characterization of genetic diversity of animal and human Mycobacterium avium strains by IS1245-IS1311 spacer typing. Vet Med Cz 4: 175-180

PEZZOTI G, SERAFIN A, LUZZI I, MIONI R, MILAN M, PERIN R 2003: Occurrence and resistance to antibiotics of Campylobacter jejuni and Campylobacter coli in animals meat in northeastern Italy. Int J Food Microbiol 82: 281-287

PRICE LB, JOHNSON E, VAILES R, SILBERGELD E 2005: Fluoroqinolone-resistant Campylobacter isolates from conventional and antibiotic-free chicken products. Environ Health Perspect 113: 557-560

RÖNNER AC, ENGVALL EO, ANDERSON L 2004: Species identification by genotyping and determination of antibiotic resistance in Campylobacter jejuni and Campylobacter coli from humans and chickens in Sweden. Int J Food Microbiol 96: 173-179

SNELLING WJ, MATSUDA M, MOORE JE, DOOLEY JSG 2005: Campylobacter jejuni under the microscope. Lett Appl Microbiol 41: 297-302

STEINHAUSEROVÁ I, NEBOLA M 2002: Je drůbež nejčastější příčinou onemocnění kampylobakteriózou u člověka? Veterinářství 52: 63- 65

TEUBER M 2001: Veterinary use and antibiotic resistance. Curr Opin Microbiol 4: 493-499 